\title{
MAPLE-MODEL OF MOVEMENT OF PARTICLE ON AN INCLUDED PLANE IN THE FUNCTION OF PARAMETER OF MOVEMENT
}

\section{A.V. Nesvidomin, Candidate of Technical Sciences, Senior Lecturerвикладач \\ National University of Life and Environmental Sciences of Ukraine}

E-mail: a.nesvidomin@gmail.com

\begin{abstract}
In many technological processes of agricultural production there is a movement of particles of material on an inclined plane. Determination of the laws of motion of a particle on the plane of an arbitrary position in three-dimensional space allows to perform the calculation of structural-kinematic parameters of the working bodies.

Computer simulation of particle motion allows to replace cumbersome analytical transformations and provide a dialog mode for carrying out the necessary computational experiments to analyze the motion of a particle under different initial conditions of its throwing on any rough surface, which is in a certain way located in space.

The purpose of the study is to develop a Maple-model of the motion of a particle on an inclined plane as a function of its motion parameter.

The use of the the Darboux trihedron allowed to reduce the law of motion of a particle to a system of two differential equations to determine the velocity and curvature of the particle trajectory.

The law of motion of a particle along a rough inclined plane was obtained in the function of it 's motion on a plane in projections to the $T$ and $P$ orts of the Darboux trihedron OTPN.
\end{abstract}

The trajectories $\boldsymbol{r}(u)$ and velocity graphs $V(u)$ of a particle along an inclined plane with a different angle of inclination from the vertical position for different throwing angle, initial velocity and coefficient of friction were obtained. The particle motion under appropriate initial conditions is analyzed.

Simulation of the motion of a particle on a rough surface in the function of its motion allows to study its trajectory-kinematic properties on a given area of the surface.

The choice of the accompanying trihedron of trajectory OuvN or OTPN does not affect the obtained results of the trajectory-kinematic properties of the motion of the particle, although it is indicated in the sequence of derivation of its law of motion.

Key words: accompanying trihedron, material point, inclined plane, trajectory of motion 
Topicality. In many technological processes of agricultural production there is a movement of particles of material on rough work surfaces in the form of an inclined plane. Establishing patterns of motion of a particle (as a material point) on the rough surface of an arbitrary position in three-dimensional space allows to calculate the structuralkinematic parameters of the working bodies.

Analysis of recent research and publications. Analytical derivation of the law of motion of a particle on any rough surface is reduced to the compilation of a system of differential equations of the 2 nd order, whose required dependencies are the trajectory of the particle, its velocity, acceleration, the length of the traveled path, the force of the normal reaction, the time of motion to its stop and other trajectory - kinematic characteristics. The sequence of analytical transformations in the derivation of the differential equation system and the methods for solving it are quite labour intensive. In recent decades, no significant changes in the automation of methods for deriving the laws of motion of a particle on a rough surface of complex shape have occurred. In existing studies, each scientist individually performs analytical transformations in order to obtain the law of motion of a particle in the form of systems of 2 nd order differential equations, the complexity of which depends essentially on the shape of the surface.

Computer simulation of particle motion on rough surfaces allows to reject cumbersome analytical transformations and to provide the scientist with convenient dialog mode for carrying out necessary computational experiments on analysis of particle motion under different initial conditions of throwing it on any rough surface, which is in a certain way located in space [2 ]. However, the development of computer models of particle motion on the surface requires the development of a general algorithm for the automatic derivation of the system of differential equations of the law of motion of the particle on any surface arbitrarily located in space; analysis of trajectory-kinematic characteristics of particle motion not only in time, but also the position of the particle and the direction of its movement on the surface; implementation of approximate methods of solving systems of differential equations to refine the results of research in the form of numerical data, graphical images and simulation models of reproduction of particle motion on the surface. 
The purpose of the study - is to develop a Maple-model of movement of particle on an included plane in the function of parameter of movement.

Materials and methods of research. The parametric equation of the $u v$-coordinate grid $\boldsymbol{R}(u, v)$ of the inclined plane in the Oxyz coordinate system can be represented as [3]:

$$
\boldsymbol{R}(u, v)=\boldsymbol{R}[u,-v \sin (\xi), v \cos (\xi)],
$$

where: $u \in\left[u_{o} ; u_{n}\right], v \in\left[v_{o} ; v_{n}\right]$ - independent internal coordinates of the plane; $\xi$ - the angle of rotation of the vertical plane around the axis $O x$.

If we substitute the expressions $u=u, v=\int \frac{\sqrt{G}}{\sqrt{E}} \operatorname{ctg}(\alpha(u)) d u$, into the inclined plane equation (1), then its trajectory $r(\alpha(u))$ in the Cartesian coordinate system $O x y z$ will look like this:

$$
r(\alpha(u))=r\left[u,-\left(\int \operatorname{ctg}(\alpha(u)) d u\right) \cdot \sin (\xi),\left(\int \operatorname{ctg}(\alpha(u)) d u\right) \cdot \cos (\xi)\right] .
$$

By equations (1) and (2) we define::

- the vector of the tangent $\boldsymbol{\tau}(\alpha(u))$ trajectory $\boldsymbol{r}(\alpha(u))$ :

$$
\tau(\alpha(u))=\tau\left[1,-\frac{\cos (\propto(u)) \sin (\zeta)}{\sin (\propto(u))}, \frac{\cos (\propto(u)) \cos (\xi)}{\sin (\propto(u))}\right] ;
$$

- the vector of the normal $\boldsymbol{n}(\alpha(u))$ trajectory $\boldsymbol{r}(\alpha(u))$ :

$$
\boldsymbol{n}(\alpha(u))=\boldsymbol{n}\left[\frac{\frac{d}{d u} \propto(u) \cos (\propto(u))}{\sin (\propto(u))^{3}}, \frac{\frac{d}{d u} \propto(u) \sin (\zeta)}{\sin (\propto(u))^{2}},-\frac{\frac{d}{d u} \propto(u) \cos (\zeta)}{\sin (\propto(u))^{2}}\right] ;
$$

- vector $\boldsymbol{P}(\alpha(u))=\boldsymbol{N} \times \boldsymbol{\tau}$ of the Darboux trihedron OTPN:

$$
\boldsymbol{P}(\alpha(u))=\boldsymbol{P}\left[-\frac{\cos (\alpha(u))}{\sin (\alpha(u))},-\sin (\xi), \cos (\xi)\right]
$$

- cosines of angles $\varphi$ and $\psi$ between vector $\boldsymbol{G}[0,0,-1]$ and vectors $\boldsymbol{\tau}$ and $\boldsymbol{P}$ :

$$
\begin{gathered}
C \varphi(\alpha(u))=\cos (\varphi)=\cos (\widehat{\boldsymbol{G}, \boldsymbol{\tau}})=-\cos (\alpha(u)) \cos (\xi), \\
C \psi(\alpha(u))=\cos (\psi)=\cos (\widehat{\boldsymbol{G}, \boldsymbol{P}})=-\sin (\alpha(u)) \cos (\xi)
\end{gathered}
$$


- the cosine and sine of the angle $\varepsilon$ between the normal $\boldsymbol{N}$ of the surface and the normal $\boldsymbol{n}$ of the trajectory $\boldsymbol{r}$ :

$$
\begin{gathered}
C \varepsilon(\alpha(u))=\cos (\varepsilon)=\cos (\widehat{\boldsymbol{N}, \boldsymbol{n}})=0, \\
S \varepsilon(\alpha(u))=\sin (\varepsilon)=\operatorname{sqrt}(1-C \varepsilon \cdot C \varepsilon)=1 .
\end{gathered}
$$

We obtain the obtained expressions into the system of differential equations [3]

$$
\left\{\begin{array}{c}
O T:=m W_{\tau}=F_{g} \cos (\widehat{\boldsymbol{G}, \tau})-f\left(F_{g} \cos (\widehat{\boldsymbol{G}, \boldsymbol{N}}) \pm F_{C} \cos (\widehat{\boldsymbol{n}, \boldsymbol{N}})\right) \\
O P:=m W_{n} \sin (\widehat{\boldsymbol{n}, \boldsymbol{N}})=F_{g} \cos (\widehat{\boldsymbol{G}, \boldsymbol{P}})
\end{array}\right.
$$

where we obtain the law of motion of a particle on a rough inclined plane in projections on the $\boldsymbol{T}$ and $\boldsymbol{P}$ of the Darboux trihedron $\boldsymbol{O T P N}$ in the form (Fig. 1,a):

$$
\left\{\begin{array}{c}
O T=m V(\alpha) \frac{d}{d \alpha} V(\alpha) k(\alpha)=-m g \cos (\alpha) \cos (\xi)-f m g \sin (\xi) \\
O P=m V(\alpha)^{2} k(\alpha)=m g \sin (\alpha) \cos (\xi)
\end{array} .\right.
$$

The required parameters of the system of equations (11) are velocity $V(\alpha)$ and curvature $k(\alpha)$. We find them using the dsolve operator dsolve $\left(\left\{O T, O P, V\left(\alpha_{o}\right)=V_{o}\right\},\{V(\alpha), k(\alpha)\}\right)$. Then we obtain such explicit equations of the velocity of the particle $V(\alpha)$ and the curvature $k(\alpha)$ of its trajectory:

$$
\begin{gathered}
V(\alpha)=\frac{V_{0} \sin \left(\alpha_{0}\right)(\operatorname{cosec}(\alpha)-\operatorname{ctg}(\alpha))^{-f \tan (\phi)}}{\sin (\alpha)\left(\operatorname{cosec}\left(\alpha_{0}\right)-\operatorname{ctg}\left(\alpha_{0}\right)\right)^{-f \tan (\phi)}}, \\
k(\alpha)=\frac{g \sin (\alpha)^{3}\left(\left(\operatorname{cosec}\left(\alpha_{0}\right)-\operatorname{ctg}\left(\alpha_{0}\right)\right)^{-f \tan (\phi)}\right)^{2}}{V_{o}^{2} \sin \left(\alpha_{0}\right)^{2}\left((\operatorname{cosec}(\alpha)-\operatorname{ctg}(\alpha))^{-f \tan (\phi))^{2}} .\right.}
\end{gathered}
$$

For an absolutely smooth $(f=0)$ inclined plane, the equation of the velocity of the particle $V(\alpha)$ and the curvature $k(\alpha)$ of its trajectory will have the following form:

$$
\begin{gathered}
V(\alpha)=\frac{V_{0} \sin \left(\alpha_{0}\right)}{\sin (\alpha)}, \\
k(\alpha)=\frac{g \sin (\alpha)^{3} \cos (\alpha)}{V_{0}^{2} \sin \left(\alpha_{0}\right)^{2}} .
\end{gathered}
$$


Note that for a perfectly smooth inclined plane at $\alpha \rightarrow \pi V(\alpha) \rightarrow \infty$ and $k(\alpha) \rightarrow 0$ - the velocity of the particle moving along the formation of the largest slope of the plane will increase indefinitely.

To construct the trajectory of a particle in the inner $u, v$-coordinates of the inclined plane $\boldsymbol{R}(u, v)$ must be solved by the system of differential equations:

$$
\left\{\begin{array}{l}
\frac{d}{d \alpha} u(\alpha)=\frac{\sin (\alpha)}{k(\alpha)}, \\
\frac{d}{d \alpha} v(\alpha)=\frac{\cos (\alpha)}{k(\alpha)},
\end{array}\right.
$$

which for a perfectly smooth and rough inclined plane will be respectively:

$$
\left\{\begin{array}{l}
\frac{d}{d \alpha} u(\alpha)=\frac{V_{o}^{2} \sin \left(\alpha_{o}\right)^{2}}{g \sin (\alpha)^{2} \cos (\xi)}, \\
\frac{d}{d \alpha} v(\alpha)=\frac{V_{o}^{2} \sin \left(\alpha_{o}\right)^{2} \cos (\alpha)}{g \sin (\alpha)^{3} \cos (\xi)},
\end{array}\right.
$$

and

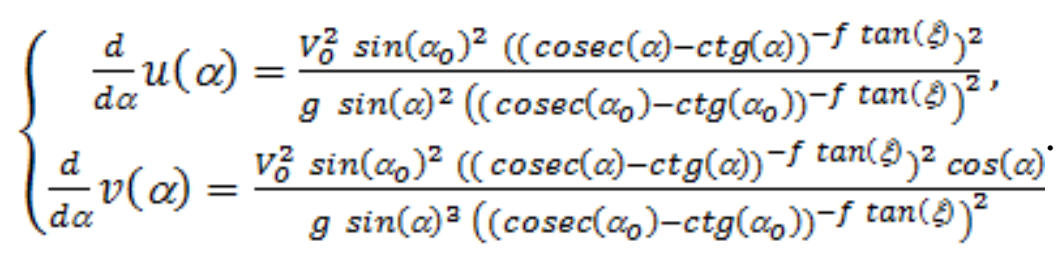

Only the differential equation system (17) can be explicitly solved. Then we obtain the internal $u, v$-coordinates of the particle's trajectory from the angle $\alpha$ :

$$
\begin{gathered}
u(\alpha)=\frac{V_{o}^{2} \sin \left(\alpha_{0}\right)\left(\cos \left(\alpha_{0}\right) \sin (\alpha)-\sin \left(\alpha_{0}\right) \cos (\alpha)\right)}{g \cos (\zeta) \sin (\alpha)}+u_{o}, \\
v(\alpha)=\frac{V_{o}^{2}\left(\sin (\alpha)^{2}-\sin \left(\alpha_{0}\right)^{2}\right)}{2 g \cos (\zeta) \sin (\alpha)^{2}}+v_{o} .
\end{gathered}
$$

Substituting them into equation (1) of the inclined plane $\boldsymbol{R}(u, v)$ leads to the parametric equation of the trajectory $\boldsymbol{r}(\alpha)$ of the particle on an absolutely smooth surface in the Cartesian $O x y z$ y coordinate system as a function of the independent parameter $\alpha$ the direction of motion of the particle: 


$$
r(\alpha)=r\left[\begin{array}{c}
\frac{V_{0}^{2} \sin \left(\alpha_{0}\right)\left(\cos \left(\alpha_{0}\right) \sin (\alpha)-\sin \left(\alpha_{0}\right) \cos (\alpha)\right)}{g \cos (\xi) \sin (\alpha)}+u_{o} \\
-\left(\frac{V_{o}^{2}\left(\sin (\alpha)^{2}-\sin \left(\alpha_{0}\right)^{2}\right)}{2 g \cos (\xi) \sin (\alpha)^{2}}+v_{o} \alpha\right) \sin (\xi) \\
\left(\frac{V_{o}^{2}\left(\sin (\alpha)^{2}-\sin \left(\alpha_{0}\right)^{2}\right)}{2 g \cos (\xi) \sin (\alpha)^{2}}+v_{o}\right) \cos (\xi)
\end{array}\right] .
$$

Results of the studies and their discussion. In Fig. 1b shows the trajectories $\boldsymbol{r}(\alpha)$ of the particle depending on the initial angle $\alpha_{o}=10^{\circ} ; 30^{\circ} ; 60^{\circ} ; 85^{\circ}$ its throw at initial values $V_{o}=4 \mathrm{~m} / \mathrm{s}, \xi=60^{\circ}, u_{o}=v_{o}=0$ over the interval of the independent variable $\alpha \in\left[\alpha_{o} ; \pi-\alpha_{o}\right]$. The trajectories of the $r(\alpha)$ particle along a perfectly smooth inclined plane are paraboles, and therefore the graphs of their curvature $k(\alpha)$ will be symmetric curves with respect to the ordinate $\alpha=\pi / 2$.

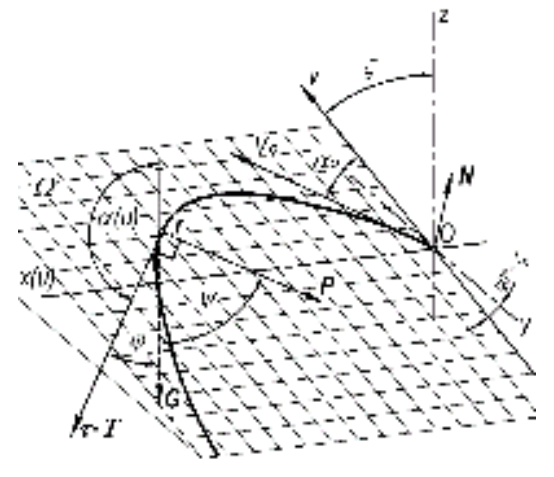

$a$

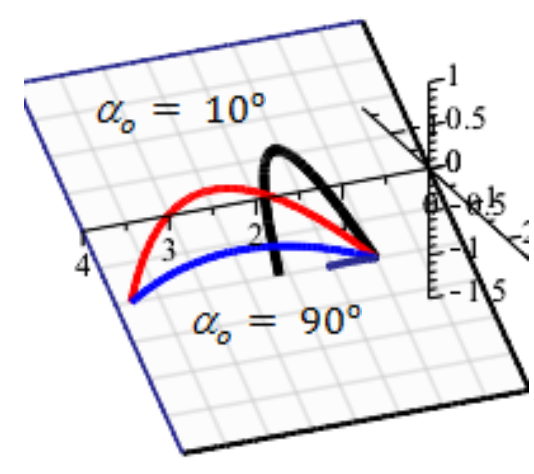

6

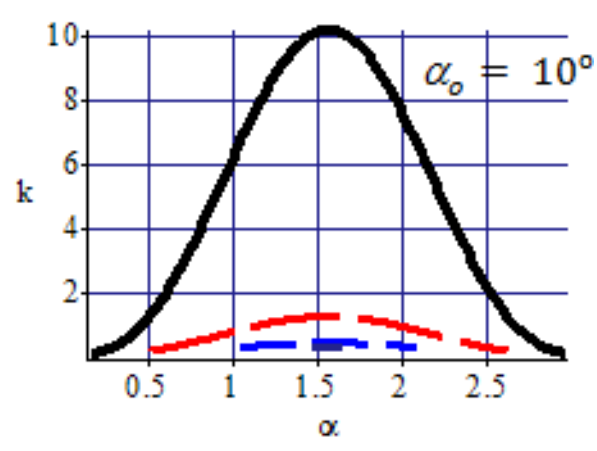

B

Fig. 1. Formation of the law of motion of a particle on an inclined plane:

a - in projections on the orths of the Darboux trihedron; $\sigma$, в - the trajectories of the particle along an absolutely smooth inclined plane and their curvatures for different angles $\alpha_{o}$

For the rough $(f \neq 0$ inclined plane $\boldsymbol{R}(u, v)$ it is no longer possible to explicitly solve the differential equation system (18), and therefore the approximate methods must be used to construct the trajectory $r(\alpha)$ of the particle. At the same time, the velocity $V(\alpha)$ and the curvature $k(\alpha)$ of the trajectories $\boldsymbol{r}(\alpha)$ of the particle on the rough surface are explicitly defined (14)-(15). In Fig. 2 graphs of the velocity $V(\alpha)$ of the particle at different angles $\xi$ 
of the plane slope and the initial velocity $V_{o}$ of the particle at constant values of the friction coefficient $f=0.3$ of the particle and the angle $\alpha_{o}=60^{\circ}$ of its throw are plotted. From the velocity graph $V(\alpha)$ we can see (Fig. 2a) that at an initial velocity $V_{o}=4 \mathrm{~m} / \mathrm{c}$ the particle slowly stops in the vicinity of $\alpha \approx 2.8$, if the angle of inclination of the plane is equal to $\xi=85^{\circ}$. For the value of the angle $\xi=75^{\circ}$ about the slope of the plane, the particle will sooner stop when it enters the "straight" trajectory $\alpha \rightarrow \pi$. For an angle $\xi=70^{\circ}$ about the slope of the plane, the particle will never stop at any initial velocity $V_{o}$ - it will first slow its velocity to a certain value, but then pick it up by going to the "straight" line of the plane. The nature of the velocity change $V(\alpha)$ of the particle will be different depending on the value of its initial velocity $V_{o}$ (Fig. 2b). In particular, for an inclined plane $\xi=70^{\circ}$ a particle with an initial velocity $V_{o}=8 \mathrm{M} / \mathrm{c}$ decreases its velocity to a value of $V_{\min } \approx 3 \mathrm{M} / \mathrm{c}$, and then gains it more infinitely in the vicinity of $\alpha \rightarrow \pi$ compared to particle, the initial velocity which was $V_{o}=2 \mathrm{~m} / \mathrm{c}$. Graphs of the velocity $V(\alpha)$ of the particle to its complete stop (the angle of inclination of the plane $\xi=75^{\circ}$ ) re shown in Fig. 2, the higher the initial velocity $V_{o}$ of the particle, the faster it stops in the vicinity of $\alpha \rightarrow \pi$.

In general, the particle will always stop if $\tan (\pi / 2-\xi)<f$. For example, for the angle $\xi=75^{\circ}$ about the slope of the plane from the vertical position we have $\tan (\pi / 2-\xi)=0.26<f=0.3$. Thus, for any value of the friction coefficient $f$ there is a limit value of the angle $\xi$ of the plane slope that divides the beam of planes from the $O x$ into sectors in which the particle will stop or not. In particular, for the friction coefficient $f=0.3$ the boundary angle $\xi$ of the plane's slope from its vertical position will be equal to 
$90^{\circ}-\operatorname{arctg}(f) \approx 73.4^{\circ}$. To find the velocity of a particle at the time of its exit on the "straight" trajectory, it is necessary to substitute the angle $\alpha=\pi$. to equation (14). But in this case we get a 0/0 uncertainty. Applying the boundary (operator limit [2]) to expressions (14) and (15), provided that the angle $\xi$ of the plane slope is equal to the coefficient $f$ of friction $(f \tan (\xi)=1)$, results in the following values:

$$
\begin{gathered}
V_{\pi}=\operatorname{limit}(V(\alpha), \alpha=\pi)=\frac{V o}{2}\left(1-\cos \left(\alpha_{o}\right)\right), \\
k_{\pi}=\operatorname{limit}(k(\alpha), \alpha=\pi)=0 .
\end{gathered}
$$
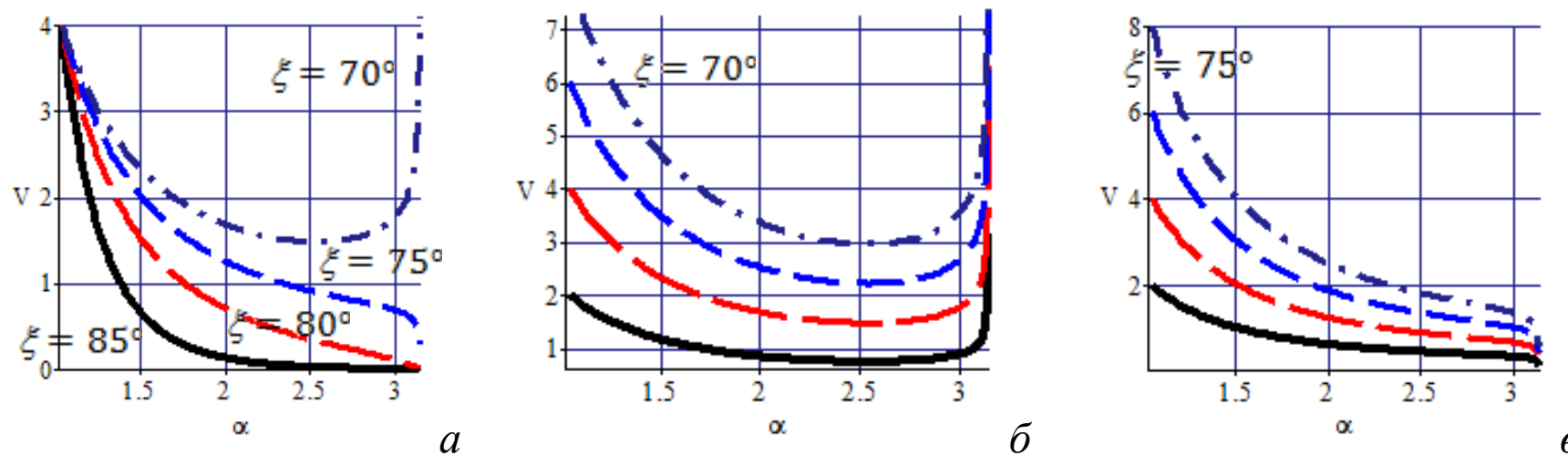

Fig. 2. Graphs of velocity $V(\alpha)$ of a particle provided:

$a$-the slope of the plane $\xi=85^{\circ}, 80^{\circ}, 75^{\circ}, 70^{\circ} ; \sigma-$ the slope of the plane $\xi=75^{\circ}$ and the initial velocity $V_{o}=2,4,6,8 ; 8$ - the slope of the plane $\xi=70^{\circ}$ and the initial velocity

$$
V_{o}=2,4,6,8
$$

Assertion. When the particles of the material with the initial velocity $V_{o}$ are fed perpendicularly $\left(\alpha_{o}=\pi / 2\right)$ to the line of the largest slope of the rough plane, set at an angle of friction to the horizon, each particle after its transition to a "straight" trajectory will move at a constant velocity $V_{o} / 2$ conditions of absence of air resistance. Bulk material thrown along the line of greatest slope $\left(\alpha_{o}=\pi\right)$ of the plane will move at a constant initial velocity $V_{o}$. If you throw it in the opposite direction $\left(\alpha_{o}=0\right)$, it will stop. 
Note that for the horizontal plane $(\xi=\pi / 2)$ it is not possible to obtain the trajectory equation $\boldsymbol{r}(\alpha)$ H since its curvature $k(\alpha)$ is zero and the system of differential equations (11) degenerates

For a vertical plane $(\xi=0)$ system $(11)$ has the following form:

$$
\left\{\begin{array}{c}
\text { OT: }=m V(\alpha) \frac{d}{d \alpha} V(\alpha) k(\alpha)=-m g \cos (\alpha) \\
O P:=m V(\alpha)^{2} k(\alpha)=m g \sin (\alpha)
\end{array} .\right.
$$

The result of using the operator dsolve $\left(\left\{O T, O P, V\left(\alpha_{o}\right)=V_{o}\right\},\{V(\alpha), k(\alpha)\}\right)$ with initial conditions $V\left(\alpha_{o}\right)=V_{o}$ is the dependence of the velocity $V(\alpha)$ of the particle and the curvature $k(\alpha)$ of its trajectory on the variable angle $\alpha(u)$ :

$$
\begin{gathered}
V(\alpha)=\frac{V o \sin \left(\alpha_{0}\right)}{\sin (\alpha)}, \\
k(\alpha)=\frac{g \sin (\alpha)^{3}}{V_{0}^{2} \sin \left(\alpha_{0}\right)^{2}} .
\end{gathered}
$$

According to the obtained equation of the curvature $k(\alpha)$ we form two differential equations of the trajectory $\boldsymbol{r}(\alpha)$ of the particle in the internal $u, v$-coordinates:

$$
\begin{gathered}
\frac{d}{d \alpha} u(\alpha)=\frac{\sin (\alpha)}{k}=\frac{V_{o}^{2} \sin \left(\alpha_{o}\right)^{2}}{g \sin (\alpha)^{2}}, \\
\frac{d}{d \alpha} v(\alpha)=\frac{\cos (\alpha)}{k}=\frac{\cos (\alpha) V_{o}^{2} \sin \left(\alpha_{0}\right)^{2}}{g \sin (\alpha)^{3}} .
\end{gathered}
$$

Their solution under the initial conditions $u\left(\alpha_{o}\right)=u_{o}$ and $v\left(\alpha_{o}\right)=v_{o}$ the position of the particle at the moment $\alpha=\alpha_{o}$ its motion by the dsolve operator:

$$
\text { dsolve }\left(\left\{\begin{array}{c}
\frac{d}{d \alpha} u(\alpha)=\frac{V_{o}^{2} \sin \left(\alpha_{o}\right)^{2}}{g \sin (\alpha)^{2}}, \frac{d}{d \alpha} v(\alpha)=\frac{v_{o}^{2} \cos (\alpha) \sin \left(\alpha_{o}\right)^{2}}{g \sin (\alpha)^{2}}, \\
u\left(\alpha_{o}\right)=u_{o}, v\left(\alpha_{o}\right)=v_{o}
\end{array}\right\},\{u(\alpha), v(\alpha)\}\right),
$$

there are explicit equations $u(\alpha)$ and $v(\alpha)$ of the trajectory $r(\alpha)$ of the particle in the internal $u, v$ - coordinates: 


$$
\begin{gathered}
u(\alpha)=-\frac{V_{o}{ }^{2} \sin \left(\alpha_{0}\right)^{2} \cos (\alpha)}{g \sin (\alpha)}+\frac{V_{o}{ }^{2} \cos \left(\alpha_{0}\right)\left(1-\cos \left(\alpha_{0}\right)^{2}\right)+u_{o} \sin (\alpha) g}{g \sin \left(\alpha_{0}\right)}, \\
v(\alpha)=-\frac{V_{o}^{2} \sin \left(\alpha_{0}\right)^{2}}{2 g \sin (\alpha)^{2}}+\frac{V_{0}{ }^{2}+2 v_{0} g}{2 g} .
\end{gathered}
$$

Substituting them into the vertical plane equation $\boldsymbol{R}(u, v)$ leads to the parametric equation of the trajectory $\boldsymbol{r}(\alpha)$ of the particle in the Cartesian system Oxyz:

$$
r(\alpha)=\boldsymbol{r}\left[\begin{array}{c}
-\frac{V_{o}{ }^{2} \sin \left(\alpha_{0}\right)^{2} \cos (\alpha)}{g \sin (\alpha)}+\frac{V_{o}^{2} \cos \left(\alpha_{0}\right)\left(1-\cos \left(\alpha_{0}\right)^{2}\right)+u_{o} \sin (\alpha) g}{g \sin \left(\alpha_{0}\right)} \\
0, \\
-\frac{V_{o}{ }^{2} \sin \left(\alpha_{0}\right)^{2}}{2 g \sin (\alpha)^{2}}+\frac{V_{o}^{2}+2 g v_{0}}{2 g}
\end{array}\right]
$$

By equating the trajectory $\boldsymbol{r}(\alpha)$ of a particle in a vertical plane, it can be stated that its construction can be carried out at the interval of the angular parameter $\alpha \in\left[\alpha_{0} ; \pi[\right.$, where $\alpha_{0}>0$ - is its initial value. Because the trajectory $\boldsymbol{r}(\alpha)$ of the free motion of a particle is a parabola, which is a symmetric curve about the vertical axis through its vertex, at the interval $\alpha \in\left[\alpha_{0} ; \pi-\alpha_{0}\right], \alpha_{0}<\pi / 2$, the initial and the endpoints of the trajectory are in the same horizontal plane.

In Fig. 3. shows the trajectories $r(\alpha)$, velocity graphs $V(\alpha)$ and curvature $k(\alpha)$ at the interval of the independent parameter $\alpha \in\left[\alpha_{0} ; \pi-\alpha_{0}\right]$ with different initial velocity $V_{o}=2,4,6,8 \mathrm{M} / \mathrm{c}$ particles at constant angle $\alpha_{o}=30^{\circ}$ of its throw. In contrast to the graphs above, they are plotted in Fig. 3b, in the velocity graphs $V(\alpha)$ and curvature $k(\alpha)$ are symmetric - the symmetry axis passes through the value of the variable parameter $\alpha=\pi / 2$. It is at this point that the particle is at the highest point of the trajectory (Fig. 3a), where the velocity $V(\alpha)$ of the particle is the smallest and is equal to $V=V_{o} \sin \left(\alpha_{o}\right)$, and the curvature $k(\alpha)$ of the trajectory $r(\alpha)$ will be the largest $-k=\frac{g}{V_{o}^{2} \sin \left(\alpha_{0}\right)^{2}}$. For a particle thrown at an angle $\alpha_{o}=\pi / 2$, ii its velocity at the beginning of the motion will be $V=V_{o}$, 
and its curvature will be $-k=\frac{g}{V_{o}^{2}}$. If the particle is thrown vertically upwards $\left(\alpha_{o}=0\right)$, then equation (26) of the curve $k(\alpha)=\frac{g \sin (\alpha)^{3}}{V_{o}^{2} \sin \left(\alpha_{0}\right)^{2}}$ characterizes the trajectory along a straight line.

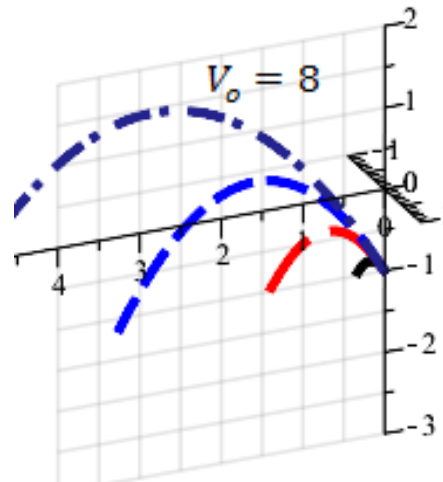

$a$

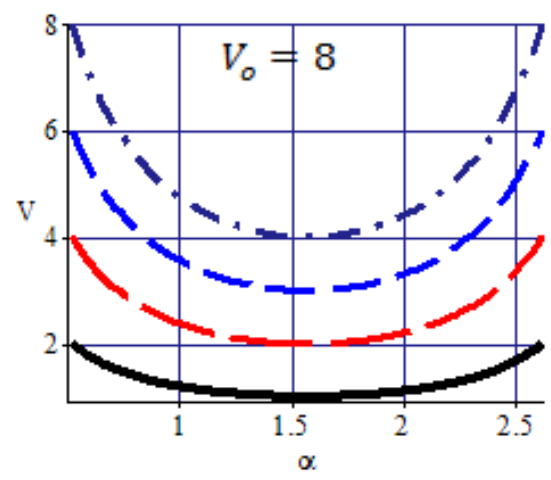

$\sigma$

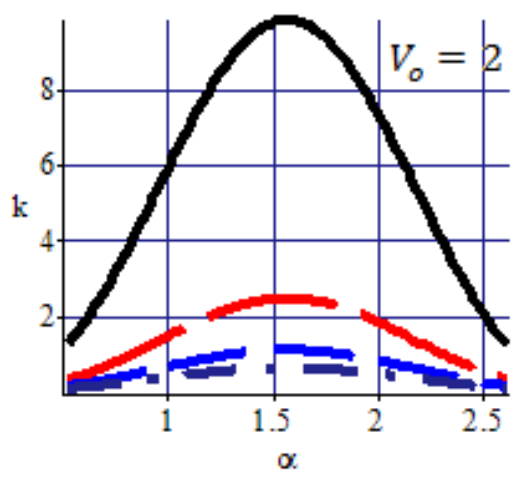

B

Fig.2.3. Particle motion for different values of initial velocity $V_{o}$ : $a$ - the trajectori $r(\alpha) ; \sigma$ - velocity graph $V(\alpha) ; \beta$ - graph of curvature $k(\alpha)$

The length $S(\alpha)$ of the arc of the path traveled by a particle depending on the angle $\alpha$ of the direction of its movement is found by the solution of the differential equation of the form:

$$
\text { dsolve }\left(\left\{\frac{d}{d \alpha} S(\alpha)=\frac{1}{k(\alpha)}, S\left(\alpha_{o}\right)=0\right\}, S(\alpha)\right)
$$

we get:

$$
S(\alpha)=\frac{v_{0}^{2}}{2 g}\left(-\frac{\sin \left(\alpha_{0}\right)^{2} \cos (\alpha)}{\sin (\alpha)^{2}}+\cos \left(\alpha_{o}\right)+\sin \left(\alpha_{o}\right)^{2}\left(\ln \left(\frac{1-\cos (\alpha)}{\sin (\alpha)}\right)+\ln \left(\frac{1-\cos \left(\alpha_{0}\right)}{\sin \left(\alpha_{0}\right)}\right)\right)\right) .
$$

In Fig. 4 graphs of the traveled path $S(\alpha)$ by a particle, its velocity $V(\alpha)$ and the curvature $k(\alpha)$ of the trajectory at the interval of the parameter $\alpha \in\left[\alpha_{0} ; \pi-\alpha_{o}\right]$ д for different angles of its throw $\alpha_{o}=10^{\circ}, 30^{\circ}, 60^{\circ}, 85^{\circ}$ at initial velocity $V_{o}=4 \mathrm{M} / \mathrm{c}$. From the constructed images, it can be seen that, regardless of the angle of throw $\alpha_{o}$ the smallest distance $S(\alpha)$ and with the smallest velocity $V(\alpha)$ the particle will fly in the vicinity of the 
parameter $\alpha=\pi / 2$ - at the highest point of the trajectory $\boldsymbol{r}(\alpha)$, where the curvature values $k(\alpha)$ is the largest.

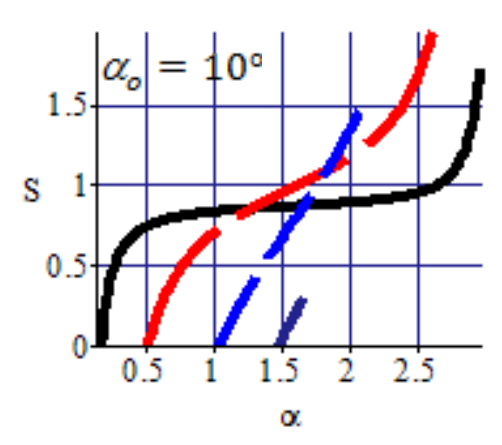

$a$

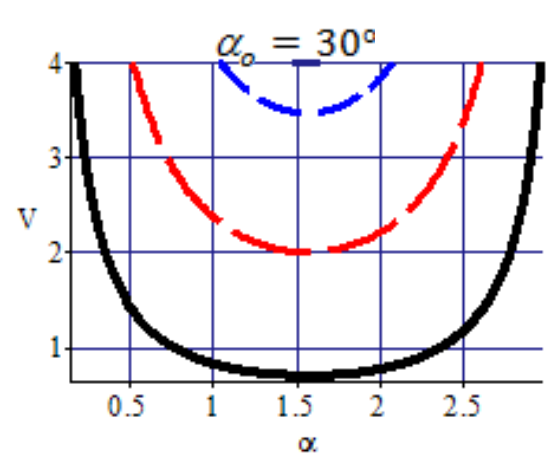

$\sigma$

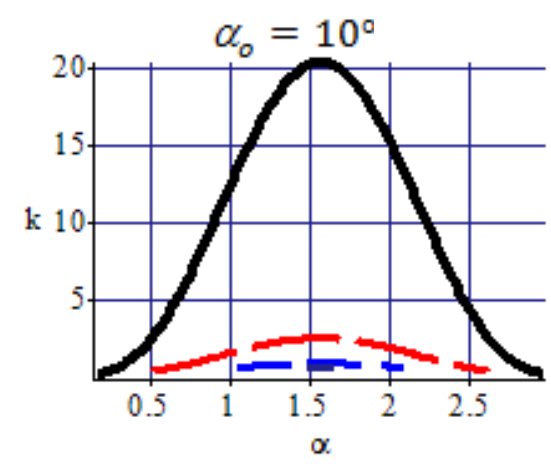

B

Fig. 4. Particle motion depending on the angle of throw $\alpha_{o}$ :

$a$ - the length of the traveled path $S(\alpha) ; \sigma$ - velocity $V(\alpha) ; \beta$ - the curvature $k(\alpha)$ of the trajectory $\boldsymbol{r}(\alpha)$

\section{Conclusions and Perspective.}

1. 1. A computer-oriented method for modeling particle motion on a rough surface has been shown to be general and effective.

2. The use of accompanying trihedron of a particle trajectory allowed to reduce the law of motion of a particle to a system of two differential equations, which are required by the internal $u, v$ - coordinates of the surface of the particle trajectory. The trajectory of the particle $r$ in the Cartesian coordinate system Oxyz is obtained by substituting the found $u, v$-coordinates to the equation $\boldsymbol{R}(u, v)$ of the surface.

3. The use of the independent parameter $\alpha$ - the direction of motion of the particle on the surface made it possible to obtain the dependences of its velocity $V(\alpha)$ and the curvature $k(\alpha)$ of the curvature of the trajectory $r(\alpha)$ in an explicit form, which is not possible for independent parameters $t$ and $u$.

4. The choice of an OUvN or OTPN accompanying trihedron does not affect the obtained results of the trajectory-kinematic properties of the particle motion, although it is indicated in the sequence of its law of motion, but the use of an $\boldsymbol{O T P N}$ trihedron is more 
natural to describe the motion of a particle on the surface as a function of an independent parameter $\alpha$.

\section{Список літератури}

1. Адамчук В.В. Теория центробежных рабочих органов машин для внесения минеральных удобрений: монография / В.В. Адамчук. - К.: Аграрна наука, 2010. $178 \mathrm{c}$.

2. Аладьев В.3. Программирование и разработка приложений в Maple / В.3. Аладьев, В.К. Бойко, Е.А. Ровба. - Гродно-Таллин, 2007. - 458 с.

3. Пилипака С.Ф. Автоматизація моделювання руху частинки по гравітаційних поверхнях на прикладі похилої площини в системі Maple / С.Ф. Пилипака, А.В. Несвідомін // Прикл. геом. та інж. граф. - К.: КНУБА, 2011. - Вип.86. - С.64-69.

\section{References}

1. Adamchuk, V. V. (2010). Teoriya tsentrobezhnykh rabochikh organov mashin dlya vneseniya mineral'nykh udobreniy: monografiya [Theory of centrifugal working bodies of machines for the application of mineral fertilizers]. Kyiv: Agrarna nauka, 178.

2. Alad'yev, V. Z., Boyko, V. K., Rovba, E. A. (2007). Programmirovaniye i razrabotka prilozheniy $\mathrm{v}$ Maple [Programming and application development in Maple]. Grodno-Tallin, 458.

3. Pylypaka, S. F., Nesvidomin, A. V. (2011). Avtomatyzatsiia modeliuvannia rukhu chastynky po hravitatsiinykh poverkhniakh na prykladi pokhyloi ploshchyny $\mathrm{v}$ systemi Maple [Automation of modeling of a particle motion on gravitational surfaces on an example of an inclined plane in the system Maple]. Prykl. heom. ta inzh. hraf. Kyiv: KNUBA, 86, 64-69.

\section{МАРЦЕ-МОДЕЛЬ РУХУ ЧАСТИНКИ ПО ПОХИЛІЙ ПЛОЩИНІ В ФУНКЦӤ ПАРАМЕТРА П̈̈ ПЕРЕМЩЩЕННЯ}

\section{А. В. Несвідомін}

Анотація. $\quad$ б багатьох технологічних процесах сільськогосподарського виробництва має місце рух частинок матеріалу по похилій площчиі. Визначення закономірностей руху частинки по площчині довільного положення в тривимірному просторі дозволяє виконати розрахунок конструктивно-кінематичних параметрів робочих органів.

Комп'ютерне моделювання руху частинки дозволяє замінити громіздкі аналітичні перетворення $i$ забезпечити діалоговий режим для проведення необхідних обчислювальних експериментів 3 аналізу руху частинки за різними вихідними умовами ї̈ кидання по будь-якій цорсткій поверхні, яка певним чином розташована в просторі.

Мета дослідження - розробка Maple-моделі руху частинки по похилій площчині у функиії параметра ї̈ переміщення. 
Застосування супровідного тригранника Дарбу дозволило звести закон руху частинки до системи із двох диференціальних рівнянь для визначення швидкості та кривизни траєкторії частинки.

Отриманий закон руху частинки по шорсткій похилій площині у функиї переміщення ї̈ на площинні в проекціях на орти $\boldsymbol{T}$ i $\boldsymbol{P}$ тригранника Дарбу ОTPN.

Отримані траєкторії $\boldsymbol{r}(u)$ та графіки швидкостей $V(u)$ частинки по похилій площині з різним кутом нахилу ї̈ від вертикального положення для різного кута кидання, початкової швидкості та коефіцієнта тертя. Проаналізований рух частинки за відповідних початкових умов.

Моделювання руху частинки по шорсткій поверхні у функиії ї̈ переміщння дозволяє дослідити ї̈ траєкторно-кінематичні властивості на заданій діляниі поверхні.

Вибір супровідного тригранника траєкторії OuvN чи OTPN не впливає на одержані результати траєкторно-кінематичних властивостей руху частинки, хоча позначається в послідовності виведення ії закону руху.

Ключові слова: супровідний тригранник, матеріальна точка, похила площина, траєкторія руху

\section{МАРЦЕ-МОДЕЛЬ ДВИЖЕНИЯ ЧАСТИЦЫ ПО НАКЛОННОЙ ПЛОСКОСТИ В ФУНКЦИИ ПАРАМЕТРА ЕЕ ПЕРЕМЕЩЕНИЯ}

\section{А. В. Несвидомин}

Аннотация. Во многих технологических процессах сельскохозяйственного производства имеет место движение частии материала по наклонной плоскости. Определение закономерностей движения частиць по плоскости произвольного расположения в трехмерном пространстве позволяет выполнить расчет конструктивно-кинематических параметров рабочих органов.

Компьютерное моделирование движения частиць позволяет заменить громоздкие аналитические преобразования и обеспечить диалоговый режим для проведения необходимых вычислительных экспериментов по анализу движения частииы с различными исходными условиями ее бросание по любой шероховатой поверхности, определенным образом расположенной в пространстве.

Цель исследования - разработка Maple-модели движения частиць по наклонной плоскости в функиии параметра ее перемещения.

Применение сопроводительного трехгранника Дарбу позволило свести закон движения частиць в систему из двух дифференщиальных уравнений для определения скорости и кривизны траектории частицьл.

Получен закон движения частицы по шероховатой наклонной плоскости в функиии перемещения ее на плоскости в проекциях на орты Т и Р трехгранника Дарбу OTPN.

Получены траектории $r(u)$ и графики скоростей V(u) частицыь по наклонной плоскости с разным углом наклона ее от вертикального положения для всех углов 
бросания, начальной скорости и коэффициента трения. Проанализировано движение частиць при соответствующих начальных условий.

Моделирование движения частищь по шероховатой поверхности в функиии ее перемещения позволяет исследовать ее траекторно-кинематические свойства на заданном участке поверхности.

Выбор сопроводительного трехгранника траектории OuvN или OTPN не влияет на полученные результаты траекторно-кинематических свойств движения частииы, хотя сказывается в последовательности вывода ее закона движения.

Ключевые слова: сопроводительный трехгранник, материальная точка, наклонная плоскость, траектория движения 